\title{
Editorial
}

\section{Focus Particles in the Romance and Germanic Languages Corpus-based and Experimental Approaches}

\author{
Anna-Maria De Cesare (Basel) and Cecilia Andorno (Torino)
}

This special issue of Linguistik online is devoted to a specific class of function words, to which the English literature refers as focus particles/focus adverbs (following e.g. König 1991). Focus particles have been defined as an autonomous category only in the last 40 years (cf. the pioneer works by Altmann 1976, 1978 and Jacobs 1983 on German Gradpartikeln, followed mainly by Nølke 1983 on French adverbes paradigmatisants, Moser 1992 on English and König 1991 on English and German focus particles/adverbs; for Italian, see the studies of Ricca 1999 as well as Andorno 2000 on avverbi focalizzanti/focalizzatori). Typically, three types of focus particles are distinguished: additive, restrictive and scalar. The prototypical members of the additive, restrictive and scalar focus particles class are E. also/only/even, G. auch/nur/sogar, I. anche/solo/persino, Fr. aussi/seulement/même etc.

The interest for focus particles lies in the fact that they are very basic from a variety of point of views, but rather complex in other respects. From a morphological point of view, they tend to be simple forms (the prototypical members of the class are mainly monomorphemic: see Ramat/Ricca 1994), but their syntactic behavior is quite complex, because of the interaction between rules concerning scope marking and the sentence information structure; from a semantic point of view, focus particles express basic semantic features (quantification and/or scales), but they also work on the discourse and pragmatic levels in raising a variety of implicatures and contributing to discourse cohesion; from a psycholinguistic point of view, they are at the core of the lexicon of a number of different languages: these forms are very frequent in all registers and genres (see again Ramat/Ricca 1994) and are acquired very early on in both L1s and L2s (see Nederstigt 2003 on German; Jordens 2012 on Dutch; Gayraud 2004 on French; Andorno 2000, 2005 and Giuliano 2012 on Italian; Benazzo et al. 2004 for a comparative perspective; also see the references in Benazzo/Dimroth, in this issue).

While other function words, such as discourse/logical connectives (expressing consequence, cause etc., such as consequently, because...), discourse particles (regulating verbal interactions such as like, okay, so, etc.) and modal particles (such as German halt, doch, schon) continue to attract a great deal of attention, the class of focus particles is comparatively under-researched and only a few aspects have been investigated. Most of the research currently available on the subject focuses on the syntactic and semantic properties of one or more prototypical members of the focus particles class. Moreover, most of the research available to date explores focus particles in single languages and on the basis of short, invented examples. Consequently, we need more studies that explore the actual use of focus particles in real discourse and specifically in different types of texts and language varieties. 
We also need more analyses that take into account several languages at once, i.e. which adopt a cross-linguistic perspective. Finally, we need more research based on a solid empirical foundation.

Over the past decade, several research centers on focus particles developed across Europe. While the research object is the same, the methods, goals and tools used in these centers to explore the semantic and syntactic properties as well as the functions performed by focus particles in discourse vary significantly. Specifically, in contrast to most of the literature produced so far on focus particles, which tend to consider only single languages (see for instance Dimroth 2004; Sudhoff 2010 and Poźlewicz 2011 on German; La Forgia 2006 on Italian), in the past few years several important studies taking into account more than one language have been produced as well. These contrastive studies show that within one and the same language family focus particles can vary quite significantly from a semantic, syntactic and discourse point of view (Sudhoff 2012) and, conversely, that there are sometimes more similarities between languages belonging to different genetic families (see for instance Ureña Gómez-Moreno 2009 on English and Spanish, as well as De Cesare, in press on English, German, French and Italian).

This special issue of Linguistik online comprises seven papers, written by 15 authors from 10 Universities in France, Germany, Italy, Spain and Switzerland. Following on the widely held belief that comparative analyses (i.e. classically contrastive, typological and/or historicalcomparative) of similar linguistic forms are a very fruitful method in achieving a better understanding of the organization of a basic notional domain and in describing how the linguistic resources at hand in different languages are used to structure text and discourses (cf., among others, Blumenthal 1985; Foolen 1989; Lauwers 2006; Gast 2006; Gast/van der Auwera 2011; Dimroth et al. 2010; Borreguero Zuloaga 2011; Sudhoff 2012), the papers included in this special issue discuss data from three Romance (Italian, French, Spanish) and three Germanic languages (German, Dutch and English).

Amongst the most innovative aspects of these papers, we can mention the following points: they offer (i) research exploring the actual use of focus particles in real discourse and, specifically, in different texts types and language varieties; in this issue, focus particles are investigated through data coming from written and spoken language sources, in adult and child production, in L1 and L2, in production and perception; (ii) research on focus particles based on different methodologies; (iii) contrastive analyses of focus particles within and among language families.

The data and methods used in the research presented in this volume differ in the following ways: some scholars employ corpus data (from original and/or translated texts: see De Cesare; Gast/Rzymski; Nicklaus), others favor elicited ones, in the form of film-retelling (Dirmoth/Benazzo; Andorno/Turco; Giuliano). The empirical data collected is then analyzed through quantitative and/or qualitative methods developed within Corpus Linguistics, Computational Linguistics and Psycholinguistic experimental research. Most studies are devoted to the investigation of linguistic production data, with analysis intertwining the textual and the syntactic level (De Cesare; Nicklaus; Giuliano; Benazzo/Dimroth), or the syntactic and the prosodic level (Andorno/Turco). Loureda et al., on the other hand, focus on the analysis of cognitive behavior in reading, through the use of eye-tracking techniques. 
Part of the discussion is also devoted to assessing the methods to be used in corpora annotation (Gast/Rzymski in relation to E. even).

Most of the papers included in this issue offer a comparative analysis of focus particles belonging to two (cf. Andorno/Turco on Italian and German additive focus particles; Giuliano on Italian and English additive and restrictive focus particles) or more than two languages (see Dimroth/Benazzo on prototypical additive particles in French, Italian, German and Dutch; De Cesare on the same particles in Italian, French and English and Nicklaus on the translation of restrictive focus particles from German into Italian and French).

We would like to thank all our colleagues who contributed a paper to this issue. We believe that, collectively, the research presented here greatly improves our understanding of how basic cognitive categories such as addition, restriction and scalarity are linguistically codified, how the linguistic expressions available vary from a cross-linguistic point of view and how they are involved in discourse organization. Moreover, the research presented in this special issue further highlights the syntactic and semantic properties of focus particles by describing their use in real language data.

We also wish to thank our colleagues who kindly accepted to review the contributions included in the volume: Giuliano Bernini (Bergamo), Tom Fritzsche (Potsdam), Manuela Caterina Moroni (Trento), Daniela Pirazzini (Bonn), Davide Ricca (Torino), Sarah Schimke (Münster), Pedro Ureña Gómez-Moreno (Granada) and Jacqueline Visconti (Genova).

Finally, we are indebted to the Swiss National Science Foundation for supporting the organization of the International Exploratory Workshop entitled Additive and Restrictive Quantification in Discourse. Comparative Perspectives (SNSF Grant IZ32Z0_148594), held in Geneva on July 26 and 27, 2013, during the $19^{\text {th }}$ International Congress of Linguists, where first versions of all the papers collected in the present special issue have been presented.

\section{References}

Altmann, Hans (1976): Die Gradpartikeln im Deutschen. Untersuchungen zu ihrer Syntax, Semantik und Pragmatik. Tübingen: Niemeyer.

Altmann, Hans (1978): Gradpartikel-Probleme. Zur Beschreibung von gerade, genau, eben, ausgerechnet, vor allem, insbesondere, zumindest, wenigstens. Tübingen: Narr.

Andorno, Cecilia (2000): Focalizzatori fra connessione e messa a fuoco. Il punto di vista delle varietà di apprendimento. Milano: FrancoAngeli.

Andorno, Cecilia (2005): "Additive and restrictive particles in Italian as a second language. Embedding in the verbal utterance structure". In: Hendriks, Henriëtte (ed.): The Structure of Learner Varieties. Berlin/New York, de Gruyter Mouton: 405-444.

Benazzo, Sandra/Dimroth, Christine/Perdue, Clive/Watorek, Marzena (2004): "Le rôle des particules additives dans la construction de la cohésion discursive en langue maternelle et en langue étrangère". Languages 155: 76-105.

Blumenthal, Peter (1985): "Aussi et auch: deux faux amis?". Französisch heute 2: 144-150.

Borreguero Zuloaga, Margarita (2011): "Focalizzatori a confronto: anche vs. también". Studi italiani di linguistica teorica ed applicata XL/3: 441-468.

De Cesare, Anna-Maria (2002): Intensification, modalisation et focalisation. Les différents effets des adverbes proprio, davvero et veramente. Bern etc.: Lang. 
De Cesare, Anna-Maria/Borreguero Zuloaga, Margarita (2014): "The contribution of the Basel Model to the description of polyfunctional discourse markers. The case of It. anche, Fr. aussi and Sp. también". In: Pons Bordería, Salvador (ed.): Discourse Segmentation in Romance Languages. Amsterdam-Philadelphia, John Benjamins: 55-94. (= Pragmatics and Beyond New Series, vol 250).

De Cesare, Anna-Maria (In press): "Defining Focusing Modifiers in a cross-linguistic perspective. A discussion based on English, German, French and Italian". In: Pittner, Karin/Elsner, Daniela/Barteld, Fabian (eds.): Adverbs - Functional and Diachronic Aspects. Amsterdam-Philadelphia, John Benjamins. (= Studies in Language Companion Series).

Dimroth, Christine (2004): Fokuspartikeln und Informationsgliederung im Deutschen. Tübingen: Stauffenburg.

Dimroth, Christine/Andorno, Cecilia/Benazzo, Sandra/Verhagen, Josie (2010): "Given claims about new topics. How Romance and Germanic speakers link changed and maintained information in narrative discourse". Journal of Pragmatics 42: 3328-3344.

Foolen, Ad (1989): "Zur Semantik und Pragmatik der restriktiven Gradpartikeln: only / nur und maar / alleen". In: Weydt, Harald (ed.): Partikeln und Interaktion. Tübingen, Niemeyer: 188-199.

Gast, Volker (2006): "The distribution of also and too - a preliminary corpus study". Zeitschrift für Anglistik und Amerikanistik 54/2: 163-176.

Gast, Volker/van der Auwera, Johan (2011): "Scalar additive operators in the languages of Europe". Language 87/1: 2-54.

Gayraud, Frédérique (2004): "Émergence et développement du placement des particules de portée". Acquisition et Interaction en Langue Étrangère 20: 173-196.

Giuliano, Patrizia (2012): "Discourse cohesion in narrative texts: The role of additive means in Italian L1 and L2". In: Watorek, Marzena/Benazzo, Sandra/Hickmann, Maya (eds.): Comparative Perspectives on Language Acquisition: A Tribute to Clive Perdue. Bristol (UK), Multilingual Matters: 375-400.

Jacobs, Joachim (1983): Fokus und Skalen. Zur Syntax und Semantik der Gradpartikeln im Deutschen. Tübingen: Niemeyer.

Jordens, Peter (2012): Language Acquisition and the Functional Category System. Berlin: de Gruyter Mouton.

König, Ekkehard (1991): The Meaning of Focus Particles. A Comparative Perspective. London: Routledge.

La Forgia, Francesca (2006): "Alcune osservazioni sui focalizzatori". Studi italiani di linguistica teorica e applicata 35/2: 359-385.

Lauwers, Peter (2006): "Aussi vs ook. Une analyse contrastive de deux adverbes polyfonctionnels". In: Mourón Figueroa, Cristina/Moralejo Gárate, Teresa Iciar (eds.): Studies in Contrastive Linguistics. Proceedings of the 4th International Contrastive Linguistics Conference. Santiago de Compostela, Universidade, Servizo de Publicacións e Intercambio Científico: 479-491.

Moser, Megan (1993): "Focus Particles: Their definition and relational structure". In: Canakis, Costas P./Chan, Grace P. (eds.): Papers from the 28th Regional Meeting of the Chicago Linguistic Society, vol. 1. Chicago, Chicago Linguistic Society: 397-411. 
Nederstigt, Ulrike (2003): Auch and noch in child and adult German. Berlin: de Gruyter Mouton.

Nølke, Henning (1983): Les adverbes paradigmatisants: fonction et analyse. Copenhagen: Akademisk Forlag. (= Revue romane 23 ).

Poźlewicz, Agnieszka (2011): Syntax, Semantik und Pragmatik der Operatorpartikeln des Deutschen. Versuch einer Systematik. Bern etc.: Lang.

Ramat, Paolo/Ricca, Davide (1994): "Prototypical adverbs: on the scalarity / radiality of the notion of adverb". Rivista di Linguistica 6/2: 289-326.

Ricca, Davide (1999): "Osservazioni preliminari sui focalizzatori in italiano". In: Dittmar, Norbert/Giacalone Ramat, Anna (eds.): Grammatica e discorso. Studi sull'acquisizione dell'italiano e del tedesco. Tübingen, Stauffenburg: 146-164.

Sudhoff, Stefan (2010): Focus Particles in German. Syntax, Prosody, and Information Structure. Amsterdam/Philadelphia: John Benjamins.

Sudhoff, Stefan (2012): "Fokuspartikelinventare des Niederländischen und Deutschen". In: Rothstein, Björn (ed.): Nicht-flektierende Wortarten. Berlin-Boston, de Gruyter Mouton: 203-223.

Ureña Gómez-Moreno, Pedro (2009): Los focalizadores del ingles: análisis morfosintáctico y semántico-pragmático de even y also basado en corpus. Granada: Editorial de la Universidad de Granada. 